\title{
How to define an osteoporotic vertebral fracture?
}

\author{
Daniele Diacinti ${ }^{1}$, Giuseppe Guglielmi ${ }^{2}$ \\ ${ }^{1}$ Department of Radiological Sciences, Oncology and Anatomo-Pathology, University Sapienza, Rome, Italy; ${ }^{2}$ Department of Clinical and \\ Experimental Medicine, University of Foggia, Foggia, Italy \\ Correspondence to: Giuseppe Guglielmi, MD. Professor of Radiology, Department of Clinical and Experimental Medicine, University of Foggia, Viale \\ Luigi Pinto, 71100 Foggia, Italy. Email: giuseppe.guglielmi@unifg.it.
}

\begin{abstract}
A vertebral deformity (VD) is not always a vertebral fracture (VF). Because of lack of a completely satisfactory "gold standard", there is no consensus on the exact definition of a VF. Therefore, it may sometimes be difficult, especially in mild cases, to discriminate the prevalent VF from a non-fracture deformity or short vertebral height (SVH). A combined standardized approach based on qualitative and semiquantitative (SQ) vertebral assessment may be the most option to correctly identify a VD as a VF. However this visual approach for VF identification is subjective, therefore it is mandatory an adequate training and experience of radiologist to reach a good sensitivity and specificity. Vertebral morphometry, objective and reproducible method, could be used only to evaluate the severity of VFs but requires the availability of reference values of vertebral height ratios. There is actually an evidentiary basis for suggesting that a qualitative approach by expert radiologists to morphological vertebral assessment, combined SQ and morphometric methods seem to be the preferred option for the correct diagnosis of $\mathrm{VF}$ as endplate or/and cortex fracture (ECF) or severe vertebral height loss.
\end{abstract}

Keywords: Vertebral fractures (VFs); vertebral deformities (VDs); endplate or/and cortex fractures (ECFs); semiquantitative vertebral assessment (SQ vertebral assessment); algorithm-based qualitative (ABQ); vertebral morphometry

Submitted Sep 03, 2019. Accepted for publication Sep 06, 2019.

doi: 10.21037/qims.2019.09.10

View this article at: http://dx.doi.org/10.21037/qims.2019.09.10

\section{Introduction}

Vertebral fractures (VFs) are the hallmark of osteoporosis. They are the most common of all osteoporotic fractures, occurring in $15 \%$ among women $50-59$ yrs of age and in $50 \%$ among women $>85$ years of age (1-4). The majority of osteoporotic VFs are asymptomatic and occur in absence of specific trauma $(5,6)$. However, even these mild VFs could have clinical consequences for the patient because of the increased, approximately 5 -fold, risk of future fractures that may be symptomatic (7-10). Multiple VFs are associated with an increased mortality rate (11-13) and impaired quality of life (14-17). As a consequence of that, the radiologic report of a VF strongly induces the physician to introduce a full bone fragility assessment, and if necessary, offer proper anti-osteoporotic treatment. Nevertheless, their relevant clinical impact, a high percentage (mean 30\%) of the mild VFs remain undiagnosed, and then a proper therapeutic intervention is omitted (18-23). The diagnosis of VFs is usually based on the presence of a deformation of vertebral body on lateral spinal radiographs, but a vertebral deformity (VD) isn't always a VF (24,25). Because there is no consensus on the exact definition of a VF, it may sometimes be difficult to discriminate the prevalent VF from a normal variant of vertebral shape or from a vertebral deformation that may have occurred long ago especially in mild cases.

\section{VF definition}

Osteoporotic VF appears as an alteration in the shape and size of the vertebral body, associated or not to vertebral 
height loss, resulting as a wedge, end-plate (mono-or biconcave), or collapse VD. There are three approaches for VFs identification on conventional radiographic and dual $\mathrm{X}$-ray absorptiometry (DXA) spine images: a qualitative visual approach, a semiquantitative (SQ) assessment method and morphometric quantitative methods.

\section{$S Q$ method}

The visual SQ method proposed by Genant et al. (26) is more commonly used for identifying VF for vertebrae $\mathrm{T} 4$ to L4. Visualization of vertebrae T1-T3 and L5 is often limited due to overlying of the shoulders and of the pelvis, respectively. Anyway, osteoporotic VF above T4 is also very rare. Vertebra L5 is also subject to considerable morphologic variation between individuals, such that very often vertebral $\mathrm{Ha}$ measurement is much larger than posterior height (Hp). VF assessment (VFA) according to SQ method is based on vertebral height reduction. So, a vertebra is graded on visual inspection of the $\mathrm{Ha}$, middle, or Hps as normal (grade-0), mildly deformed (grade-1, a $20-25 \%$ reduction in one of the three heights and a reduction of area 10-20\%), moderately deformed (grade-2, a $25-40 \%$ reduction in any height and a reduction in area of $20-40 \%$ ), and severely deformed (grade-3, a $40 \%$ or more reduction in height and area). Congenital or acquired non-osteoporotic VDs, which may mimic osteoporotic VD (oVD) in appearances, are systemically excluded (27). Though it has been suggested that SQ method provides a good performance for the diagnosis of prevalent and incident VFs, when utilized by expert and trained radiologist (28). More recently, some authors $(29,30)$ noted that consistently and precisely estimating the extent of height loss according to Genant's criteria is difficult. In particular, Lentle et al. (31) and Wáng (30) suggested that the narrow range of Genant's SQ grade-1 height loss, i.e., $20-25 \%$, can cause much inconsistency and difficulties for population studies, and many reported epidemiological differences between regions and ethnic groups could be largely due to methodology imprecision and inconsistency. Since an osteoporotic VF does not necessarily have a height loss, or does not necessarily have a height loss $\geq 20 \%$, Wáng (30) further proposed a modified SQ criteria, i.e., mild VF with $<20 \%$ vertebral height loss; moderate mild VF with 20-34\% vertebral height loss; severe VF with $>34 \%$ vertebral height loss. Deng et al. (32) and Wáng et al. (27) reported that vertebrae with $>34 \%$ height loss always showed radiographical sign of endplate or/and cortex fracture (ECF). Thus severe grade would be always ECF (+). This modified SQ criteria may be more practical daily clinics, such as, if height loss is more than $1 / 3$ of the vertebra, then it is severe grade (approximately $>34 \%$ ); if height loss is less than $1 / 5$ of the vertebra, then it is mild grade (<20\%) (33). Worsening of a VF, e.g., progression from grade- 1 to -2 , has been commonly considered to be equivalent to an incident fracture. In a recent study, Wáng et al. (27) used the criteria that an incident fracture is defined as a qualitative VF occurred in a vertebra that was not deformed at baseline [i.e., standard deviation (SD) grade-0], which could be either a change from grade-0 at baseline to grade-2 or grade-3 VD at follow-up, or a change from grade- 0 at baseline to grade- 1 VD with at least $10 \%$ height loss during the follow-up period. If a normal vertebra (grade-0) progressed to grade-1 is considered a new VF without such height loss requirement, then there is a theoretical possibility that a qualitative VF with $18 \%$ height loss (may be graded as grade-0.5) progressed to SQ grade-1 VF with only $2 \%$ further height loss during the 4-year follow-up. This may lead to "overcall" of incident new VFs. For an existing VF at baseline, a further vertebral height loss at follow-up of at least $15 \%$ or $20 \%$ is considered as a VF worsening $(27,34)$, it was suggested that a threshold of $>15 \%$ further height loss may be more sensitive for epidemiological follow-up studies (27).

\section{Vertebral wedging}

$\mathrm{VF}$ is more frequent at midthoracic and thoracolumbar levels that are the most biomechanically compromised locations within the vertebral column $(35,36)$.

Vertebral wedging is one of the characteristic features in osteoporotic compression fractures, but may occur in healthy subjects or in developmental abnormalities with or without degenerative changes. The vertebrae bodies changes as size and as shape at different levels of the spine for the construction of thoracic-lumbar curvatures, that reduces bending moments created by upright posture and so provides stability during motion (37). So the spine normally appears with physiological wedging of the thoracolumbar vertebral bodies in healthy subjects. MRI study in asymptomatic healthy subjects, demonstrated that at the thoracolumbar junction (T11-L2 levels) the vertebral bodies are wedge-shaped with $\mathrm{A} / \mathrm{P}$ ratio of $0.92 \pm 0.08$ at $\mathrm{T} 10,0.92 \pm 0.08$ at $\mathrm{T} 11,0.90 \pm 0.06$ at $\mathrm{T} 12,0.89 \pm 0.06$ at $\mathrm{L} 1$, and $0.90 \pm 0.07$ at $\mathrm{L} 2$ (38).

On aging, anterior vertebral thoracic wedging increases, 


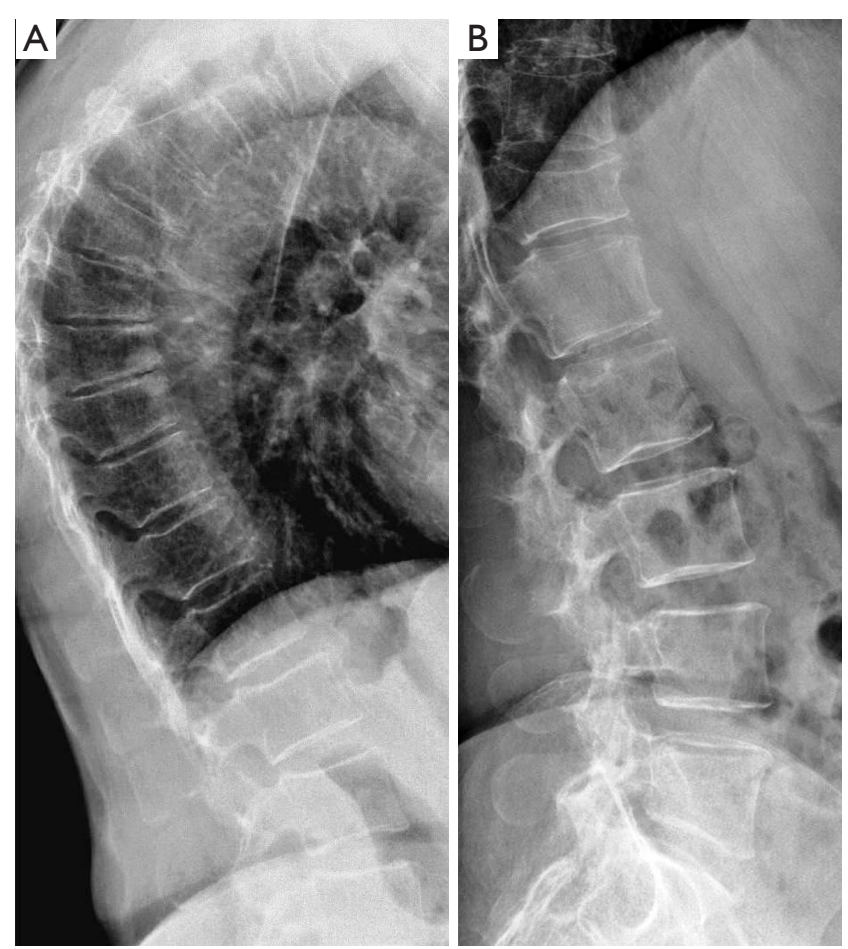

Figure 1 Radiographs shows VDs anterior wedged-shaped. (A) Moderate VDs (SQ2) anterior wedged-shaped at vertebrae T6, T7 and T8 with central endplate integrity and anterior osteophytes: wedging in osteoarthritis; (B) moderate VDs (SQ2) anterior wedged-shaped at vertebrae T12 with central endplate collapse: VF. VD, vertebral deformity; VF, vertebral fracture; SQ, semiquantitative.

so the spine bends forward, resulting in spinal deformity (kyphosis) and height loss. An anatomic study on aged cadaveric thoracic and lumbar dissected vertebrae (T1-L5), demonstrated that the vertebral bodies are anteriorly wedged from T1 through L2 (peak at T7), non-wedged at L3, and posteriorly wedged at L4-L5 (peak at L5) (39). In other studies, the vertebral $\mathrm{Ha} / \mathrm{Hp}$ ratios measured by DXA technique are resulted in women aged $70-82$ years as mean of $0.90 \pm 0.04$ at thoracic level with lower $\mathrm{A} / \mathrm{P}$ value at $\mathrm{T} 6$ as $0.83 \pm 0.05$ (40).

Therefore, the SQ method assumption that the vertebra body shape is rectangular it is incorrect.

The physiological wedging of vertebral bodies, more evident at T6-T9 spine level, should be taken into account when performing VFA using the criteria of SQ method. So, SQ approach based on vertebral heights reduction may bring equivocal diagnosis for grade- 1 VFs that are often either false positive or deformities related to non- osteoporotic diseases of the spine. The assessment of the overall aspect of the spine may help in the identifying the VFs among VDs. Wedging of the vertebral bodies has been reported to occur in patients with disorders of intervertebral disc cartilage endplates including a Schmorl's node and irregularity of the endplates as Scheuermann's disease (41). Moreover in aging population anterior vertebral wedging may be due to both underlying VF and osteoarthritis changes (42). For these reasons is particularly difficult to accurately diagnose mild wedge fractures in the midthoracic region using only SQ method based on vertebral height reduction (Figure 1).

\section{Vertebral endplate collapse: algorithm-based qualitative $(A B Q)$}

In old study (43) it was demonstrated that for differentiation between osteoporotic and osteoarthritis wedging should be evaluated, in addition to $\mathrm{Ha} / \mathrm{Hp}$ ratio, also the middle/ $\mathrm{Hp}$ ratio that is exaggerated lower in osteoporotic fracture. Next studies highlighted that there is a relationship between vertebral body deformity and disc degeneration in the aging spine. The central region of the vertebra endplate adjacent to the nucleus pulpous is the weakest area and it is exposed to greater vertical stress than other regions resulting in biconcave deformity $(44,45)$. Genant et al. (46) suggested that for VFA, in addition to vertebral height reductions, the expert and reader have to identify the vertebral shape alterations (as buckling of cortices, the lack of parallelism of endplates, etc.). However, SQ criteria do not require the presence of these radiographic fracture sign to diagnose VF. In order to improve the specificity of VF diagnosis, it has been developed an ABQ with a focus on the appearance of endplate rather than height reduction (47). On a true lateral projection, the superior (or inferior) surface of the normal vertebra exhibits two lines; one line represents one side of the vertebral ring, and the second (more dense) line represents the central endplate superimposed on the opposite vertebral ring. The ABQ assumes that all osteoporotic VFs initially involve concave depression of the center of the endplate within the vertebral ring, that is considered the weakest area. Thus, by definition, wedge and crush fractures are initially concave fractures. If the vertebral ring is displaced with fracture of the lateral or anterior cortex of the vertebral body, will be wedge or crush fracture. The non-fracture deformities with apparent "reduction" in vertebral height without endplate depression are categorized by Ferrar et al. (48) as non-osteoporotic 

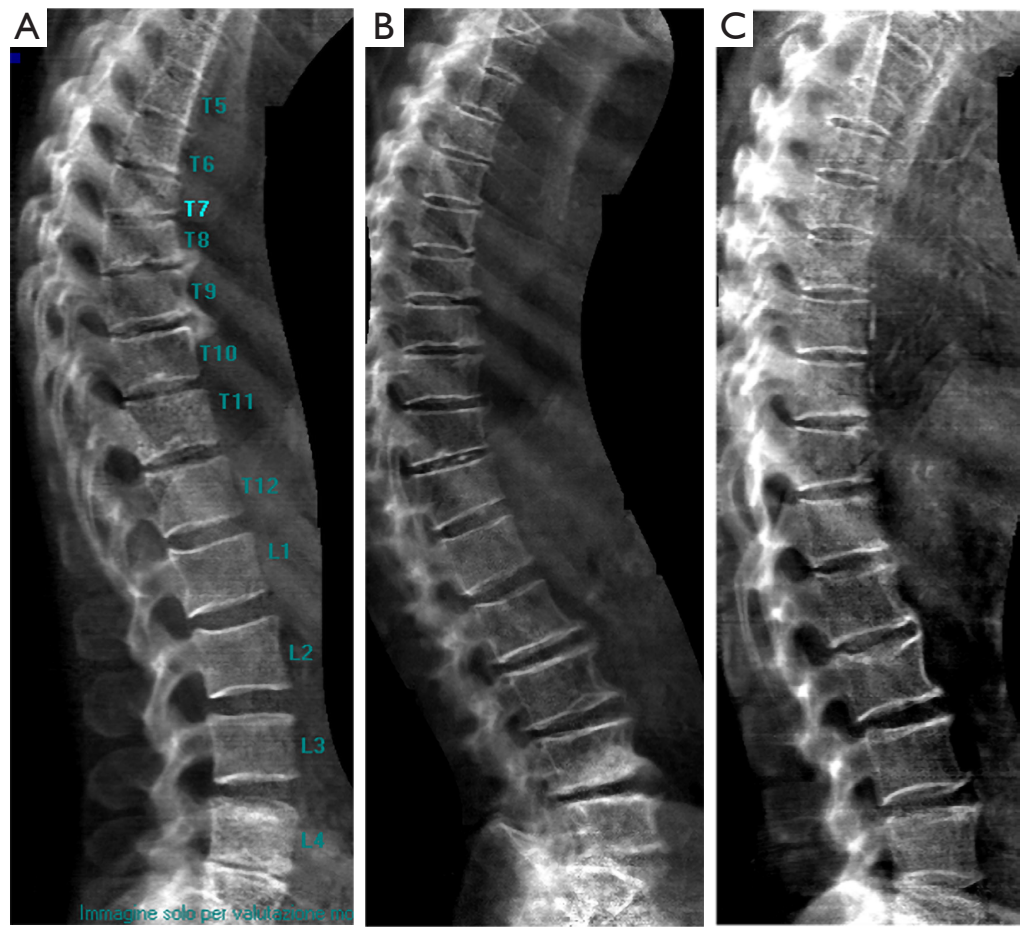

Figure 2 Vertebral wedge deformities on VFA images. (A) Mild wedge deformities (SQ1) at vertebrae T6 through T11 with undulated endplates, multiple Schmorl's nodes and disc space narrowing: Scheuermann's disease; (B) moderate wedge deformity (SQ2) at vertebra T11 with endplate integrity: wedging in osteoarthritis; (C) severe wedge deformity (SQ3) at vertebra T5; mild wedge deformity (SQ1) at vertebrae T11 and L2 with endplate and cortex fracture: VFs. VF, vertebral fracture; VFA, VF assessment; SQ, semiquantitative.

short vertebral height (SVH), as degenerative change and Scheuermann's disease (Figure 2). Patients with SVH had similar bone mineral density (BMD) values to patients with normal vertebral heights; otherwise patients with concave or biconcave VDs identified by ABQ had BMD values significantly lower. ABQ approach had interobserver agreement for radiographic diagnosis of VFs significantly better than SQ method (49). It has been demonstrated that vertebrae classified as grade-1 VF by ABQ were associated with higher risk of VFs as well as non-vertebral major osteoporotic fracture, while SQ1-VF was not associated with higher non-VF (50). Really, also ABQ method has some limits. Genant et al. assumed that endplate fracture is $100 \%$ sensitive for osteoporotic fracture (46), but ABQ approach not include anterior cortex buckling which is quite common as VF sign (Figure 3) (51). Furthermore, endplate fracture does not always occur at the center of endplate (52). Finally, the ABQ do not take account for grading the extent of vertebral height loss.

In a recent review (53) are summarized the radiographic morphological signs of osteoporotic VF detectable by an expert reader: (I) anatomic discordance between adjacent vertebrae; (II) loss of parallelism between adjacent endplates; (III) end-plate disruption as they are impacted into the vertebral body; (IV) fractures of the vertebral anterior cortex or end-plate characterized by cortical discontinuities (ECF); (V) buckling of the vertebral cortex, especially anteriorly. Compared with subjects without ECF subjects with ECF are at a higher risk of short-term (4-year period) deformity progression and new incident deformity (27). It also possible that vertebrae may fracture with pain but without measurable changes in radiographic height or area or endplate disruption and therefore in the absence of any appreciable radiographic VD (54). Furthermore, in a histologic study vertebrae radiographically classified as normal, adjacent to osteoporotic VFs, had histological evidence of endplate fracture and anterior cortical fracture (55). In these cases it is necessary to perform MR exam which may show transient vertebral marrow edema. The altered MR vertebral marrow signal reflects trabecular microcracks and repair of "occult fracture" in "unfractured" osteoporotic vertebrae (53). 


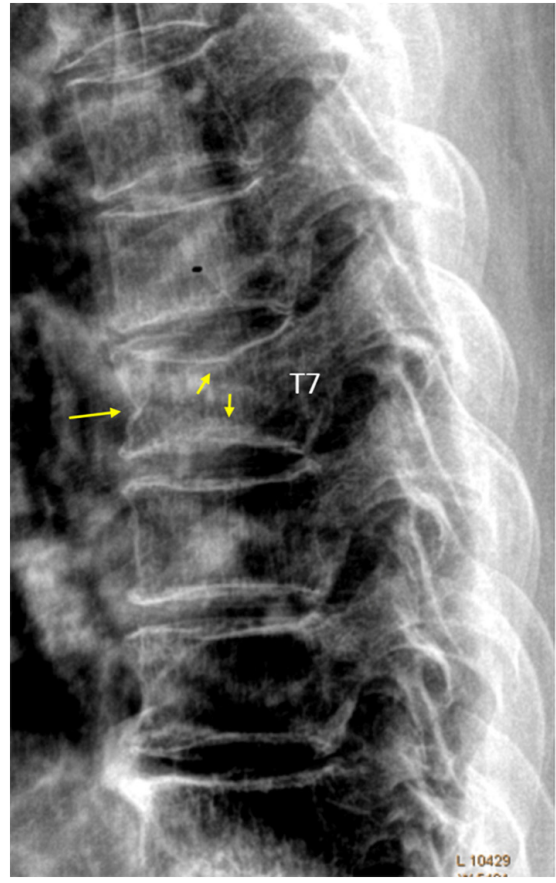

Figure 3 Vertebra T7 deformity (SQ2), with both upper and lower endplate fracture as well as anterior cortex fracture [reproduced with permission from reference (51)]. SQ, semiquantitative.

\section{Vertebral morphometry: normative data}

To reduce the subjectivity of qualitative readings has been introduced vertebral morphometry, method objective and reproducible based on measurements of vertebral height and their ratios $(56,57)$. The SQ method has been enclosed for VFA in the software for computerized vertebral morphometry performed on conventional radiographs or on images obtained by DXA. Last technique perform VFA with a lower radiation exposure dose $(<20 \mu \mathrm{Sv})$ than conventional radiography $(600 \mu \mathrm{Sv})(58)$. VFA results to be reliable and accurate in detecting VFs in adults (59-61) and children (62) with sensitivity and specificity ranging from $62 \%$ to $97 \%$ and $94 \%$ to $99 \%$ respectively (63). However, as it is a quantitative method, vertebral morphometry is unable to differentiate between osteoporotic VFs nonfracture VDs, considering also the variability of the normal radiologic appearance of the vertebrae is both among and within individuals (64). A recent study demonstrated the wide difference in osteoporotic VF prevalence when we use qualitative or morphometric radiological approaches (65). To reduce the rate of false positives among the VFs resulted by morphometric methods, normative data for vertebral body height ratios have been established, specific to the technique used (conventional plain radiographs or DXA) and to the population under study.

Some authors obtained means and SDs of vertebral bodies heights from premenopausal women, assuming that the prevalence of VFs is zero $(66,67)$. This approach involves radiation exposure for fertile women and considers nothing effect of age on vertebral morphometry, even if the results are conflicting. The prospective studies following women from pre- to post-menopause did not find a significant decrease in vertebral heights and ratios with age $(68,69)$. Conversely, all the cross-sectional studies reported vertebral heights and also $\mathrm{Ha} / \mathrm{Hp}$ ratio values significantly lower in older women compared with younger women (70-72). Understanding whether vertebral heights vary with age is necessary because it influences the choice of the normative data. In fact, if it is accepted that vertebral heights change with age, we must derive normal values from a sample of age-matched women, since a VD which may be in excess of $2 \mathrm{SD}$ from the mean in younger subjects may be well within this limit 20 years later. So, have been obtained reference values from postmenopausal women both excluding women with VFs $(73,74)$ and including women with VFs using trimming procedures remove the extreme values from the Gaussian distribution (75). To reduce the variation caused by the larger number of deformities has been recommended the use of median and percentile (76) or the use of a modified quantitative approach based on the calculation of standardized vertebral height, referred as standardized quantitative morphometry (SQM) (77). In a multicentric study, we derived reference data for vertebral morphometry by DXA technique (78) as means ( \pm SD) of raw and trimmed data and medians $[ \pm$ interquartile range (IQR)] of vertebral heights and ratios split into decades. The 1,254 Italian consecutive pre- and postmenopausal women, (mean age 63.7 \pm 11.3 ; range, $26-88$ years), enrolled in the study had the vertebral heights significantly different to UK and US women, suggesting the need to have reference data specific to the population under study.

There is still disagreement about establishing a threshold of height reduction, which would allow unequivocal discrimination between VFs, VDs, and normal shape. Various morphometric algorithms to define VFs have been developed comparing the $\mathrm{Ha}$ or middle height to the $\mathrm{Hp}$ within a vertebra and the Hp to the Hp of the adjacent vertebrae above or below (predict posterior) $(79,80)$. Overall, as described by Eastell-Melton and McCloskey $(81,82)$, a prevalent $\mathrm{VF}$ is defined on the baseline spine 
images (radiographs or VFA) if any of the three ratios, $\mathrm{Ha} / \mathrm{Hp}$, central/Hp (Hm/Hp), posterior/predicted $\mathrm{Hp}$ $\left(\mathrm{Hp} / \mathrm{Hp}^{+1}\right.$ or $\left.\mathrm{Hp} / \mathrm{Hp}^{-1}\right)$, is $<3 \mathrm{SD}$ the corresponding reference ratio value obtained from population of normal fertile women. Using this method, if the reference T6 $\mathrm{Ha} / \mathrm{Hp}$ ratio result, for example, $0.83 \pm 0.05$ (mean $\pm \mathrm{SD}$ ), the vertebra $\mathrm{T} 6$ may be considered as VF when the $\mathrm{Ha} / \mathrm{Hp}$ is $<0.68$, that is the same as $32 \%$ reduction of anterior vertebral height. Therefore, the vertebral height reduction of $20 \%$ proposed in SQ method as threshold for VF cannot applicable to any subject, and in the same subject at any spine level. It is necessary the comparison between the vertebral height ratios of examined patient with reference data using cut-off of $<3 \mathrm{SD}$ to vertebral level mean value or more stringent morphometric criteria (mean-4SD). When we used vertebral morphometry it is necessary to compare the measured vertebral dimensions with normative data. So, as quantitative computed tomography (QCT) and DXA use specific for race, sex and age reference values to evaluate $\mathrm{BMD}$, we suggest to include in the vertebral morphometry software the reference vertebral height ratios specific for the population and probably even for age groups to identify VFs with better accuracy for both epidemiological studies and clinical practice.

Finally, it should be noted that osteoporotic VFs of elderly men and elderly women have distinctly different features, and the above descriptions are primarily based on research results for women. Deng et al. (83) demonstrated that while the overall oVD prevalence is only slightly lower in elderly men than in elderly women (i.e., $13.2 \%$ vs. $16.1 \%)$, ECF prevalence is substantially lower in men than women (i.e., $5.88 \%$ vs. $11.93 \%$ ). Moreover, $63.2 \%$ of the oVDs in men were Genant's SQ grade-1, while only $30.5 \%$ of the oVDs in women were Genant's SQ grade-1. Osteoporotic VDs in males with $25-34 \%$ height loss rarely have ECF, while it is common for osteoporotic VDs in females with $25-34 \%$ height loss to be associated with ECF (32). More recently, MrOS (Hong Kong)'s year-4 follow-up shows (33), for male subjects at baseline without VD and ECF, the VD progression/new VD rate during follow-up was half of the paired MsOS (Hong Kong) study's results for females. For those with baseline VD or ECF, the VD progression/new VD was less than 1/6 of females' rate. Therefore, the clinical importance of osteoporotic VF in males remains undefined and further works are necessary. The VF evaluation schemes described in this paper are likely to be valid only for elderly women's osteoporotic VF evaluation (84).
In conclusion, we analyzed the most commonly used methods to define osteoporotic VFs. There is actually an evidentiary basis for suggesting that a combination of qualitative approach by expert radiologists to VFA seems to be the preferred option for correctly diagnose and graduate a VF $(85,86)$. At first, non-osteoporotic deformities should be ruled out by an expert reader to detect the specific morphologic signs of osteoporotic VFs, particularly ECF $(51,53)$. Once the diagnosis of VF is established, then SQ criteria (26) or modified criteria (31) is recommended to grade the severity of vertebral height loss. We suggest to utilize vertebral morphometry only to graduate more objectively the VFs, once qualitatively diagnosed. In this way the radiologist plays a central role in the management of patients with osteoporosis, but an adequate training is recommended by correctly identifying all of VFs (87).

\section{Acknowledgments}

None.

\section{Footnote}

Conflicts of Interest: The authors have no conflicts of interest to declare.

\section{References}

1. Johnell O, Kanis J. Epidemiology of osteoporotic fractures. Osteoporos Int 2005;16 Suppl 2:S3-7.

2. Cauley JA, Palermo L, Vogt M, Ensrud KE, Ewing S, Hochberg M, Nevitt MC, Black DM. Prevalent vertebral fractures in black women and white women. J Bone Miner Res 2008;23:1458-67.

3. Vitali C, Gussoni G, Bianchi G, Albanese CV, Diacinti D, Sinigaglia L, Nuti R, Muzzulini CL, Pintaudi C, Scanelli G, Magni G, Valerio A, Iori I, Mazzone A, Campanini $M$, Research Department of FADOI. High prevalence of fragility vertebral fractures in patients hospitalised in internal medicine units. Results of the POINT (prevalence of osteoporosis in internal medicine) study. Bone 2015;74:114-20.

4. Cummings SR, Melton LJ. Epidemiology and outcomes of osteoporotic fractures. Lancet 2002;359:1761-7.

5. Kim YJ, Chae Su, Kim GD, Park KH, Lee YS, Lee HY. Radiographic detection of osteoporotic vertebral fracture without collapse. J Bone Metab 2013;20:89-94.

6. Yu W, Lin Q, Zhou X, Shao H, Sun P. Reconsideration 
of the relevance of mild wedge or short vertebral height deformities across a broad age distribution. Osteoporos Int 2014;25:2609-15.

7. Pongchaiyakul C, Nguyen ND, Jones G, Center JR, Eisman JA, Nguyen TV. Asymptomatic vertebral deformity as a major risk factor for subsequent fractures and mortality: a long-term prospective study. J Bone Miner Res 2005;20:1349-55.

8. Roux C, Fechtenbaum J, Kolta S, Briot K, Girard M. Mild prevalent and incident vertebral fractures are risk factors for new fractures. Osteoporos Int 2007;18:1617-24.

9. Lindsay R, Pack S, Li Z. Longitudinal progression of fracture prevalence through a population of postmenopausal women with osteoporosis. Osteoporos Int 2005;16:306-12.

10. Broy SB. The vertebral fracture cascade: etiology and clinical implications. J Clin Densitom 2016;19:29-34.

11. Kado DM, Duong T, Stone KL, Ensrud KE, Nevitt MC, Greendale GA, Cummings SR. Incident vertebral fractures and mortality in older women: a prospective study. Osteoporos Int 2003;14:589-94.

12. Johnell O, Kanis JA, Oden A, Sernbo I, Redlund-Johnell I, Petterson C, De Laet C, Jonsson B. Mortality after osteoporotic fractures. Osteoporos Int 2004;15:38-42.

13. Bliuc D, Nguyen ND, Milch VE, Nguyen TV, Eisman JA, Center JR. Mortality risk associated with low-trauma osteoporotic fracture and subsequent fracture in men and women. JAMA 2009;301:513-21.

14. Romagnoli E, Carnevale V, Nofroni I, D'Erasmo E, Paglia F, De Geronimo S, Pepe J, Raejntroph N, Maranghi M, Minisola S. Quality of life in ambulatory postmenopausal women: the impact of reduced bone mineral density and subclinical vertebral fractures. Osteoporos Int 2004; 15:975-80.

15. Fink HA, Ensrud KE, Nelson DB, Kerani RP, Schreiner PJ, Zhao Y, Cummings SR, Nevitt MC. Disability after clinical fracture in postmenopausal women with low bone density: the Fracture Intervention Trial (FIT). Osteoporos Int 2003;14:69-76.

16. Burger H, Van Daele PLA, Gashuis K, Hofman A, Grobbee DE, Schütte HE, Birkenhäger JC, Pols HA. Vertebral deformities and functional impairment in men and women. J Bone Miner Res 1997;12:152-7.

17. Hasserius R, Karlsson MK, Jonsson B, Redlund-Johnell I, Johnell O. Long-term morbidity and mortality after a clinically diagnosed vertebral fracture in the elderly-a12and 22-year follow-up of 257 patients. Calcif Tissue Int 2005;76:235-42.
18. Kim N, Rowe BH, Raymond G, Jen H, Colman I, Jackson SA, Siminoski KG, Chahal AM, Folk D, Majumdar SR. Underreporting of vertebral fractures on routine chest radiography. AJR Am J Roentgenol 2004;182:297-300.

19. Delmas PD, van de Langerijt L, Watts NB, Eastell R, Genant HK, Grauer A, Cahall DL. Underdiagnosis of vertebral fractures is a worldwide problem: the IMPACT study, J Bone Miner Res 2005;20:557-63.

20. Williams AL, Al-Busaidi A, Sparrow PJ, Adams JE, Whitehouse RW. Underreporting of osteoporotic vertebral fractures on computed tomography. Eur J Radiol 2009;69:179-83.

21. Carberry GA, Pooler BD, Binkley N, Lauder TB, Bruce RJ, Pickhardt PJ. Unreported vertebral body compression fractures at abdominal multidetector CT. Radiology 2013;268:120-6.

22. Diacinti D, Vitali C, Gussoni G, Pisani D, Sinigaglia L, Bianchi G, Nuti R, Gennari L, Pederzoli S, Grazzini M, Valerio A, Mazzone A, Nozzoli C, Campanini M, Albanese CV; Research Department of FADOI. Misdiagnosis of vertebral fractures on local radiographic readings of the multicentre POINT (prevalence of osteoporosis in internal medicine) study. Bone 2017;101:230-5.

23. Fink HA, Litwack-Harrison S, Ensrud KE, Shen J, Schousboe JT, Cawthon PM, Cauley JA, Lane NE, Taylor BC, Barrett-Connor E, Kado DM, Cummings SR, Marshall LM, Osteoporotic Fractures in Men (MrOS) Study group Association of incident, clinically undiagnosed radiographic vertebral fractures with follow-up back pain symptoms in older men: the Osteoporotic Fractures in Men (MrOS) Study. J Bone Miner Res 2017;32:2263-8.

24. Kleerekoper M, Nelson DA. Vertebral fracture or vertebral deformity? Calcif Tissue Int 1992;50:5-6.

25. Ziegler R, Scheidt-Nave C, Leidig-Bruckner G. What is a vertebral fracture? Bone 1996;18:169S-77S.

26. Genant HK, Wu CY, van Kuijk C, Nevitt MC. Vertebral fracture assessment using a semiquantitative tech nique. J Bone Miner Res 1993;8:1137-48.

27. Wáng Y X J, Che-Nordin N, Deng M, Leung JCS, Kwok AWL, He LC, Griffith JF, Kwok TCY, Leung PC. Osteoporotic vertebral deformity with endplate/cortex fracture is associated with higher further vertebral fracture risk: the Ms.OS (Hong Kong) study results Osteoporos Int 2019;30:897-905.

28. Genant HK, Jergas M, Palermo L, Nevitt M, Valentin RS, Black D, Cummings SR. Comparison of semiquantitative visual and quantitative morphometric assessment of prevalent and incident vertebral fractures in osteoporosis. 
The Study of Osteoporotic Fractures Research Group. J

Bone Miner Res 1996;11:984-96.

29. Lentle BC, $\mathrm{Hg}$ Oei E, Goltzman D, Rivadeneira F, Hammond I, Oei L, Kovacs CS, Hanley DA, Prior JC, Leslie WD, Kaiser SM, Adachi JD, Probyn L, Brown J, Cheung AM, Towheed T. Vertebral fractures and morphometric deformities. J Bone Miner Res 2018;33:1544-5.

30. Wáng YX. A modified semi-quantitative (mSQ) grading scheme for osteoporotic vertebral fracture in elderly women. Quant Imaging Med Surg 2019;9:146-50.

31. Lentle B, Koromani F, Brown JP, Oei L, Ward L ,Goltzman D, Rivadeneira F, Leslie WD, Probyn L, Prior J, Hammond I, Cheung AM, Oei EH, Vertebral Fracture Research Groups of the CaMos, STOPP, and Rotterdam Studies. The Radiology of Osteoporotic Vertebral fractures revisited. J Bone Miner Res 2019;34:409-18.

32. Deng M, Kwok TCY, Leung JCS, Leung PC,Wáng YX . All osteoporotically deformed vertebrae with $>34 \%$ height loss have radiographically identifiable endplate/cortex fracture. J Orthop Translat 2018;14:63-6.

33. Wáng YXJ, Che-Nordin N, Deng M, Griffith JF, Leung JCS, Kwok AWL, Leung PC, Kwok TCY. Elderly males with or without existing osteoporotic vertebral fracture have much lower future vertebral fracture risk than elderly females: the MrOS (Hong Kong) year-4 follow-up spine radiograph study. Osteoporos Int 2019. [Epub ahead of print]. doi: 10.1007/s00198-019-05136-x.

34. Schwartz EN, Steinberg D. Detection of vertebral fractures. Curr Osteoporos Rep 2005;3:126-35.

35. Cooper C, O’Neill T, Silman A. The epidemiology of vertebral fractures. European Vertebral Osteoporosis Study Group. Bone 1993;14:S89-97.

36. Ismail AA, Cooper C, Felsenberg D, Varlow J, Kanis JA, Silman AJ, O’Neill TW. Number and type of vertebral deformities: epidemiological characteristics and relation to back pain and height loss. European Vertebral Osteoporosis Study Group. Osteoporos Int 1999;9:206-13.

37. Putz RL, Muller-Gerbl M. The vertebral column-a phylogenetic failure? Clin Anat 1996;9:205-12.

38. Matsumoto M, Watanabe K, Okada E, Chiba K, Momoshima S, Kaneko Y, Toyama Y, Nishiwaki Y, Ichihara D, Fujiwara H, Hashimoto T, Takahata T. Wedging of vertebral bodies at the thoracolumbar junction in asymptomatic healthy subjects on magnetic resonance imaging. Surg Radiol Anat 2011;33:223-8.

39. Masharawi Y, Salame K, Mirovsky Y, Peleg S, Dar G, Steinberg N, Hershkovitz I Vertebral body shape variation in the thoracic and lumbar spine: characterization of its asymmetry and wedging. Clin Anat 2008;21:46-54.

40. Prince RL, Devine A, Dick IM. The clinical utility of measured kyphosis as a predictor of the presence of vertebral deformities. Osteoporos Int 2007;18:621-7.

41. Tribus CB. Scheuermann's kyphosis in adolescents and adults: diagnosis and management. J Am Acad Orthop Surg 1998,6:36-43.

42. Ribom EL, Kindmark A, Ljunggren O. Hyperkyphosis and back pain are not associated with prevalent vertebral fractures in women with osteoporosis. Physiother Theory Pract 2015;31:182-5.

43. Abdel-Hamid Osman A, Bassiouni H, Koutri R, Nijs J, Geusens P, Dequeker J. Aging of the thoracic spine: distinction between wedging in osteoarthritis and fracture in osteoporosis--a cross-sectional and longitudinal study. Bone 1994;15:437-42.

44. Dai L. The relationship between vertebral body deformity and disc degeneration in lumbar spine of the senile. Eur Spine J 1998;7:40-4.

45. Ferguson SJ, Steffen T. Biomechanics of the aging spine. Eur Spine J 2003;12:S97-103.

46. Genant HK, Jergas M. Assessment of prevalent and incident vertebral fractures in osteoporosis research. Osteoporos Int 2003;14 Suppl 3:S43-55.

47. Jiang G, Eastell R, Barrington NA, Ferrar L. Comparison of methods for the visual identification of prevalent vertebral fracture in osteoporosis. Osteoporos Int 2004;15:887-96.

48. Ferrar L, Jiang G, Armbrecht G, Reid DM, Roux C, Gluer CC, Felsenberg D, Eastell R. Is short vertebral height always an osteoporotic fracture? The Osteoporosis and Ultrasound Study (OPUS). Bone 2007;41:5-12.

49. Ferrar L, Jiang G, Schousboe JT, DeBold CR, Eastell R. Algorithm-Based Qualitative and Semiquantitative Identification of Prevalent Vertebral Fracture: Agreement Between Different Readers, Imaging Modalities, and Diagnostic Approaches. J Bone Miner Res 2008;23:417-24.

50. Lentle B, Trollip J, Lian K. The radiology of osteoporotic vertebral fractures redux. J Clin Densitom 2016;19:40-7.

51. Wáng YX, Deng M, He LC, Che-Nordin MN, Santiago RF. Osteoporotic vertebral endplate and cortex fractures: a pictorial review. J Orthop Translat 2018;15:35-49.

52. Che-Nordin N, Deng M, Griffith JF, Leung JCS, Kwok AWL, Zhu YQ, So RHY, Kwok TCY, Leung PC, Wáng YX. Prevalent osteoporotic vertebral fractures more likely involve the upper endplate than the lower endplate and 
even more so in males. Ann Transl Med 2018;6:442.

53. Wáng YXJ, Santiago RF, Deng M, Nogueira-Barbosa MH. Identifying osteoporotic vertebral endplate and cortex fractures. Quant Imaging Med Surg 2017;7:555-91.

54. McKiernan FE. The broadening spectrum of osteoporotic vertebral fracture. Skeletal Radiol 2009;38:303-8.

55. Antonacci MD, Mody DR, Rutz K, Weilbaecher D, Heggeness MH. A histologic study of fractured human vertebral bodies. J Spinal Disord Tech 2002;15:118-26.

56. Nicholson PH, Haddaway MJ, Davie MW, Evans SF.

A computerized technique for vertebral morphometry.

Physiol Meas 1993;14:195-204.

57. Guglielmi G, Diacinti D, van Kuijk C, Aparisi

F, Krestan C, Adams JE, Link TM. Vertebral

morphometry: current methods and recent advances.

Eur Radiol 2008;18:1484-96.

58. Damilakis J, Adams JE, Guglielmi G, Link TM. Radiation exposure in X-ray-based imaging techniques used in osteoporosis. Eur Radiol 2010;20:2707-14.

59. Fuerst $\mathrm{T}, \mathrm{Wu} \mathrm{C}$, Genant $\mathrm{HK}$, von Ingersleben $\mathrm{G}$, Chen Y, Johnston C, Econs MJ, Binkley N, Vokes TJ, Crans G, Mitlak BH. Evaluation of vertebral fracture assessment by dual X-ray absorptiometry in a multicenter setting. Osteoporos Int 2009;20:1199-205.

60. Guglielmi G, Muscarella S, Bazzocchi A. Integrated imaging approach to osteoporosis: state-of-the-art review and update. Radiographics 2011;31:1343-64.

61. Diacinti D, Del Fiacco R, Pisani D, Todde F, Cattaruzza MS, Diacinti D, Arima S, Romagnoli E, Pepe J, Cipriani C, Minisola S. Diagnostic performance of vertebral fracture assessment by the lunar iDXA scanner compared to conventional radiography. Calcif Tissue Int 2012;91:335-42.

62. Diacinti D, Pisani D, D'Avanzo M, Celli M, Zambrano A, Stoppo M, Diacinti D, Roggini M, Todde F, D'Eufemia P, Pepe J, Minisola S. Reliability of vertebral fractures assessment (VFA) in children with osteogenesis imperfecta. Calcif Tissue Int 2015;96:307-12.

63. Lee JH, Lee YK, Oh S-H, Ahn J, Lee YE, Pyo JH, Choi Y, Kim D, Bae SC, Sung Y-K, Kim D-Y. A systematic review of diagnostic accuracy of vertebral fracture assessment (VFA) in postmenopausal women and elderly men. Osteoporos Int 2016;27:1691-9.

64. O'Neill TW, Varlow J, Felsenberg D, Johnell O, Weber K, Marchant F, Delmas PD, Cooper C, Kanis J, Silman AJ. Variation in vertebral heights ratios in population studies. J Bone Miner Res 1994;9:1895-907.

65. Oei L, Koromani F, Breda SJ, Schousboe JT, Clark
EM, van Meurs JB, Ikram MA, Waarsing JH, van Rooij FJ, Zillikens MC, Krestin GP, Oei EH, Rivadeneira F. Osteoporotic vertebral fracture prevalence varies widely between qualitative and quantitative radiological assessment methods: the Rotterdam Study. J Bone Miner Res 2018;33:560-8.

66. Smith-Bindman R, Cummings SR, Steiger P, Genant HK. A comparison of morphometric definitions of vertebral fracture. J Bone Miner Res 1991;6:25-34.

67. Rea JA, Steiger P, Blake GM, Potts E, Smith IG, Fogelman I. Morphometric X-ray absorptiometry: reference data for vertebral dimensions. J Bone Miner Res 1998;13:464-74.

68. Davies KM, Recker RR, Heaney RP. Normal vertebral dimensions and normal variation in serial measurements of vertebrae. J Bone Miner Res 1989;4:341-9.

69. Sevinc O, Barut C, Is M, Eryoruk N, Safak AA. Influence of age and sex on lumbar vertebral morphometry determined using sagittal magnetic resonance imaging. Ann Anat 2008;190:277-83.

70. Diacinti D, Acca M, D’Erasmo E, Tomei E, Mazzuoli GF. Aging changes in vertebral morphometry. Calcif Tissue Int 1995;57:426-9.

71. Gallagher JC, Hedlund LR, Stoner S, Meeger C. Vertebral morphometry: normative data. Bone Miner 1988;4:189-96.

72. Sone T, Tomomitsu T, Miyake M, Takeda N, Fukunaga M. Age-related changes in vertebral height ratios and vertebral fracture. Osteoporos Int 1997;7:113-8.

73. Melton LJ 3rd, Kan SH, Frye MA, Wahner HW, O'Fallon WM, Riggs BL. Epidemiology of vertebral fractures in women. Am J Epidemiol 1989;129:1000-11.

74. Evans SF, Nicholson PHF, Haddaway MJ, Davie MW. Vertebral morphometry in women aged 50-81 years. Bone Miner 1993;21:29-40.

75. Black DM, Cummings SR, Stone K, Hudes E, Palermo L, Steiger P. A new approach to defining normal vertebral dimensions. J Bone Miner Res 1991;6:883-92.

76. Zebaze RM, Maalouf G, Wehbe J, Nehme A, Maalouf $\mathrm{N}$, Seeman E. The varying distribution of intra- and inter-vertebral height ratios determines the prevalence of vertebral fractures. Bone 2004;35:348-56.

77. Jiang G, Ferrar L, Barrington NA, Eastell R. Standardised quantitative morphometry: a modified approach for quantitative identification of prevalent vertebral deformities. Osteoporos Int 2007;18:1411-9.

78. Diacinti D, Pisani D, Del Fiacco R, Francucci CM, Fiore CE, Frediani B, Barone A, Bartalena T, Cattaruzza MS, Guglielmi G, Diacinti D, Romagnoli E, Minisola S. 
Vertebral morphometry by X-ray absorptiometry: which reference data for vertebral heights? Bone 2011;49:526-36.

79. Lunt M, Ismail AA, Felsenberg D, Cooper C, Kanis JA, Reeve J, Silman AJ, O'Neill TW; European Prospective Osteoporosis Study Group. Defining incident vertebral deformities in population studies: a comparison of morphometric criteria. Osteoporos Int 2002;13:809-15.

80. Grados F, Roux C, de Vernejoul MC, Utard G, Sebert JL, Fardellone P. Comparison of four morphometric definitions and a semiquantitative consensus reading for assessing prevalent vertebral fractures. Osteoporos Int 2001;12:716-22

81. Eastell R, Cedel SL, Wahner HW, Riggs BL, Melton LJ. Classification of vertebral fractures. J Bone Miner Res 1991;6:207-15.

82. McCloskey EV, Spector TD, Eyres KS, Fern ED, O'Rourke N, Vasikaran S, Kanis JA. The assessment of vertebral deformity: a method for use in population studies and clinical trials. Osteoporos Int 1993;3:138-47.

Cite this article as: Diacinti D, Guglielmi G. How to define an osteoporotic vertebral fracture? Quant Imaging Med Surg 2019;9(9):1485-1494. doi: 10.21037/qims.2019.09.10
83. Deng M, Zeng XJ, He LC, Leung JCS, Kwok AWL, Griffith JF, Kwok T, Leung PC, Wáng YX. Osteoporotic vertebral fracture prevalence in elderly Chinese men and women: a comparison of endplate/cortex fracture-based and morphometrical deformity based methods. J Clin Densitom 2019;22:409-19.

84. Wáng YX, Che-Nordin N. Informed communication with study subjects of radiographically detected osteoporotic vertebral deformity. Quant Imaging Med Surg 2018;8:876-80.

85. Aubry-Rozier B, Fabreguet I, Iglesias K, Lamy O, Hans D. Impact of level of expertise versus the statistical tool on vertebral fracture assessment (VFA) readings in cohort studies. Osteoporos Int 2017;28:523-7.

86. Adams JE. Opportunistic identification of vertebral fractures. J Clin Densitom 2016;19:54-62.

87. Guglielmi G, Balzano RF, Cheng X. What is changed in the diagnosis of osteoporosis: the role of radiologists. Quant Imaging Med Surg 2018;8:1-4. 